\title{
Capitalism and Democracy: A Critical \& Investigative Analysis of the United States Government's Policy Making
}

\author{
Reza G. Hamzaee, Ph.D. \\ BOG-Distinguished Professor of Economics \\ Department of Economics, Political Science, and Sociology \\ Missouri Western State University \\ Alec Guy \\ Department of Economics, Political Science, and Sociology \\ Missouri Western State University \\ Brock Ryan \\ Department of Economics, Political Science, and Sociology \\ Missouri Western State University
}

\begin{abstract}
Policy making, put in place by the people for the purpose of serving the people, should be one of, if not the, most efficient institutions in the nation. In this research paper, the authors seek to critically evaluate U.S. policymaking and its efficiency. Currently, the policymaking process attempts to blend both democratic values and capitalistic traits. Disturbing habits, such as proposing omnibus, complicated bills proposed just before important deadlines, are being routinely practiced in congress. Negative externalities exist in the presence of extensive government regulation which ends up hurting the market it intended to help, and it is wasting taxpayers' money. This research also points out worrisome trends in the United States economy, such as the continued growth of the wealth gap and the lack of a fair minimum wage as well as any specific policy targeting an effective employability enhancement. Current legislatures have made no serious attempt to tackle either of these issues, and the authors explain why this is such a serious problem. The goal of the authors is to challenge the current policymaking process in hopes that recognition of its shortfalls may bring about changes in that process.
\end{abstract}

Key Words: Capitalism, democracy, policymaking, externalities, Employability

\section{INTRODUCTION}

Why does the American economy continue to struggle since the most recent financial crisis? Improvements have been made, but recovery has been rather slow. Of course, one must turn to the government, as well as the policies that our officials create, for answers. However, one must also look at the fundament ideologies of our country; capitalism and democracy. They seem to go hand in hand, they are championed by the strong Western nations of the world, they are predicated upon freedom and competition, and they seem to be a perfect pair. Yet, there are issues, especially in the United States. This is due to a fundamental change as countries begin to mature and age. They continue to focus on freedom, but equality becomes more important as standard of living increases. However, capitalism does not cater well to equality. In fact, it is predicated on competition, which means there are clear winners and losers; a trend that is now apparent in the US. Thomas Piketty has explained this as a scenario in which business owners overpower those in the labor force (Edsall, 2014). So, one must beg the question, are capitalism and democracy compatible, and what policies can be created to 
ensure that they are? If we are to gauge the effectiveness of America's policies, this question must be answered first. Lack of focus on policies that should be conducive to more employability of the educated and trained workers (De Vosa et al., October 2011) is another growing concern. It would be needed to implement appropriate policy focused on fostering competency development, employability and career success.

Regardless, many policies in America can already be deemed inefficient. In fact, legislators in America attempt to regulate the economy in various facets, such as subsidies for farmers, but these regulations are often ineffective. For example, subsidies cost taxpayers 20 billion dollars a year, and subsides are often paid to farmers who do not produce crops (Economist, Feb 14, 2015). From an economic and governmental perspective, this is an inefficient policy, yet there are countless policies such as this. Further, some current policies, like the Dodd-Frank legislation, are ineffective because they are too complex. The Dodd-Frank legislation, which was passed following the 2008 financial crisis, is 848 pages long, and it is 23 times the size of the legislative reform that followed the stock market crash of 1929 (Economist, Feb 16, 2012). This is not unique to Dodd-Frank either. The Affordable Care Act, or Obamacare, is also quite long, and it has been taken to the Supreme Court various times. Perry (2015) posits that there are complexities for businesses in Obamacare, which have made it difficult to comply with this policy, as well as raised the cost of providing healthcare. Clearly, policymaking in America has become extremely complex. Why is this so?

Even more problems with legislators have arisen as well. For example, legislators consistently create policies that benefit the rich, and, as such, they foster inequality. One such policy is that of trickledown economics. This was championed by President Reagan and more recently by Governor Brownback in Kansas. Duke (2015) argues that the trickle-down experiment has failed and that benefits have failed to materialize for the lower and middle class. Wealth simply does not trickle down. These policies have allowed the rich to get richer, and the poor have become even more marginalized. Why do our politicians create policies that foster inequality, which ultimately hinders the US economy? There are various reasons of course; a few being that legislators refuse to compromise when needed, politicians are being bought by lobbyists, and politicians themselves are often trying to better their own businesses or create a career path once they leave office. In regards to lobbying, Solomon (2014) explains that General Electric spent an outrageous amount of 134 million dollars from 2009 to 2014, and AT\&T spent 91.2 million dollars in the same time frame. These two companies have spent the most on lobbying during this time period, and all of this money has been dedicated to buying officials and policies favorable for these companies. In the coming sections, these problems will be addressed through review of relevant literature, and our research findings will be displayed and analyzed as a follow up to an applicable theoretical framework. At best, this paper will seek to recommend more effective policies, which would help the American economy. However, before all of this can be discussed, relevant literature on this topic must be reviewed.

\section{RELATED LITERATURE}

A critical and analytical judgement regarding the effectiveness of current socioeconomic policies in America is hopefully presented here, adequately, through an initial review of some helpful published works followed by a more systemic and theoretical framework that will be analyzed through some available evidence and data. As stated above, the relationship between capitalism and democracy must be revisited and investigated.

Almond (1991) argues that capitalism and democracy can in fact complement one another, and he posits that many other authors have argued this as well, such as Joseph Schumpeter. 
Almond explains that democracy can aid in the effectiveness of capitalism and that capitalism can aid democracy in many facets. Esposito (2014) also explains the connection between these two, stating that, together, they can help create a prosperous and peaceful future. Of course, all of this makes sense considering the basic premises of capitalism and democracy. They are both predicated upon freedom and competition, which makes them compatible. Coyne (2007) believes that capitalism can be beneficial to democracy, and he emphasizes thoughts from Milton Friedman, which state that political freedom is aided by economic freedom. Historically, the two have worked well together, and many of the industrialized Western nations have become prosperous due to these paradigms.

Yet, the related literature has demonstrated a detachment between capitalism and democracy. Many scholars are beginning to question the cohesiveness of the two ideological concepts. Despite the similar foundations of democracy and capitalism, they are also quite different. Some, like Blumen (1996), believe that democracy fosters equality and a sense of cooperation, while capitalism does the opposite and fosters competition. This is a stark difference, and is argued to have caused problems for the United States and other democracies. Democracy hopes to create equality for all, but capitalism usually creates winners and losers. Almond (1991) also explores the contradictions of democracy and capitalism by proposing that capitalism undermines democracy by fostering inequality, and that democracy undermines capitalism by regulating the economy. Esposito (2014) offers thoughts on this as well, and reaffirms that the two are growing apart due to their antithetical beliefs regarding "power, scale, and interaction." As stated above, democracy focuses on equality more and more as it matures, which is at odds with capitalism. Due to these differences, many scholars have come to believe that these ideologies are becoming incompatible.

In practical experience, the truth may be somewhere in between. Democracy and capitalism may not be a perfect pair, but they can work together in harmony. However, appropriate policies must be designed and formulated to assure this is possible. There are various aspects of capitalism that are inefficient, such as the creation of negative externalities, leading to the well known over-allocation of resources. Policies can address these issues in capitalism, but they cannot overstep as they have in the past. The American economy has become extremely regulated, and this has hindered competition. Coyne (2007) posits that rules are extremely important because they incentivize certain actions. This can allow control in an economy, which is needed to combat some weaknesses and issues of capitalism. In regards to equality, this is still achievable in a capitalistic system, even though perfect equality will never be attained. There will have to be some compromises to the ideal of capitalism in order to make up for a few shortcomings of the system, such as social welfare spending which can combat inequality and some regulation to address negative externalities. Government intervention can be beneficial for the economy in some instances. However, extensive government regulation is inefficient, and it has caused the American economy to suffer. These policies must be addressed and reformed in order for capitalism and democracy to work better with one another.

In regards to the effectiveness of current policies, there is an ongoing debate. Many believe that the U.S. Congress has grown into a rather ineffective institution, and that adopted policies are often inefficient. This was briefly touched on above, and there are multiple issues with Congress, such as lobbying and lack of compromise. However, some believe that Congress is not inefficient, and that it is functioning like the founders of our country intended. Patterson and Magleby (1992) explain that Congress was meant to act in a slow manner, and that the rules of this institution simply foster that result. To a certain extent this is accurate. When Congress was created, America's founding fathers designed the legislative branch elaborately 
and utilized a system of checks and balances. There are various safety nets between the branches of the government, but there are also some fail safes in Congress. The House is based on population, but the writers of the Constitution did not want large states to have too much power, so they created the Senate, which has equal representation from all states. Of course, this inherently slows down the process of creating policy because both houses in Congress must pass a bill in order for it to become law. As such, Congress simply cannot act as fast as citizens hope. However, the American people also elect a government which fosters inaction or, at least, sluggishness. Divided government has become the norm in America, which makes it even more difficult for Congress to function since parties have trouble compromising nowadays. Krutz (2015) explains that divided government means that the executive branch and legislative branch are not controlled by the same party, and this causes gridlock because parties use their advantage by attempting to enact policies they favor. This can be seen with today's government. The presidency is controlled by the Democrats and Congress is controlled by the Republicans. Furthermore, issues can arise when each Chamber of Congress is controlled by a different party. This has contributed to the lackluster performance of our current government. Ultimately, the presidency, House, and Senate are rarely controlled by one party, which has obstructed progress and the ability to create laws.

Consequently, Congress is unpopular in the eyes of the public. Patterson and Magleby (1992) explain that approval rates of Congress are traditionally between 27-35 percent, yet individual representatives often have a high approval rating and gain reelection. The public is often displeased with the House and the Senate because they believe the institution is ineffective and corrupt. In fact, the $113^{\text {th }}$ Congress, which took place a couple of years ago, was the most inactive session in American history. This Legislature passed 234 bills, the lowest ever, the government shut down for over two weeks during the session, and Congress' average approval rating was 14.5 percent (Topaz, 2014). As of late, the House and Senate are still plagued with inaction. In terms of economics, there are various policies that are ineffective in the United States. There are many regulations on the economy which have hindered efficiency. Of course, the aims of these policies are often laudable. For example, farmer's subsidies, which were discussed earlier, were created with intentions of aiding farmers and ensuring that they have a stable income. However, these subsidies cost a large amount of money, and they create inefficiencies in the market. Another example is low income housing. These regulations are created to assure that low income individuals can afford housing, but these price ceilings have caused excess demand for some living establishments, as well as reduced their quality. Regulations are usually imposed to help individuals or attempt to keep the economy fair, but problems often arise. Hutchinson (2013) explains that there are many excess costs in the United States, which has caused some companies to outsource jobs. He also posits that the American economy has never been extremely competitive; it has benefited mainly from its size and a lack of international competition, yet this is now changing. Given this, policies must be adjusted elaborately, or the American economy will falter.

There are also many problems with law complexity, as touched on earlier. Some argue that laws are trying to become too specific and attempting to address all problems in a single piece of legislation, but it would be more beneficial to create broad guidelines and adjust as changes need to be made (The Economist, Feb 16, 2012). This would reduce the amount of red tape businesses have to work around, which would make it easier for them to operate, as well as incentivize staying in America. Finally, policies do not favor the average American, which has caused economic inequality and, thus, economic issues. Bondioli (2014) details a survey that was conducted by researchers at Princeton and Northwestern Universities, which found that policy rarely favors the average US citizen. The authors found that regular citizens have almost 
no influence on policy, but affluent citizens, as well as interest groups, have a strong impact on the laws that are created. This can also explain why economic policies in America tend to be ineffective. The middle class, comprised of average Americans, is extremely important to a strong economy. However, policy does not take this into account. Thus, the current inequality in the United States has been able to flourish. These are a few of the reasons why some of Congress' economic policies have been ineffective as of late, and some urgent, appropriate changes must be made in order to address these shortfalls.

Despite all of this, some argue that Congress is working as intended. Rozell (2000) believes that the public is too critical of Congress. He posits that Congress works how it is supposed to, and that the representatives in the Senate and the House are generally upstanding individuals. Rozell believes that the low approval ratings arise because Congressmen and Congresswomen are more focused on local media instead of the national scene, and these individuals often criticize the entire institution to show that they are not corrupt. In terms of economic policies, Congress has created effective law in some instances. For example, government intervention during the most recent financial crisis saved us from another depression. Weller (2012) explains that three policies issued during the Recession, the Troubled Asset Relief Program, the American Recovery and Reinvestment Act, and the Tax Relief, Unemployment Insurance Reauthorization, and Job Creation Act were all critical in addressing the financial crisis. There are other examples of effective government regulation as well, such as the destruction of monopolies and the advent of workplace safety. Many believe that Congress functions as it was intended, such as Sinclair (2009), who argues that legislatures are doing an efficient job given the structure of the House and Senate. Further, many posit that some economic policies have been efficient. However, there are many who disagree with this premise.

The two views shown above, that Congress and economic policies are effective and that Congress and economic policies are ineffective, are both correct in their own sense. Congress has clearly bolstered the economy on certain occasions, and even saved the economy, but it has also hindered the economy. Given the possible relationship between capitalism and democracy, it is important that Congress considers both of these factors. Congress should be weary of intervening in the economy too much, but there are areas where intervention and policy are necessary, such as social welfare spending, breaking up monopolies, etc. One appropriate focus has always been on more widely assisted accessibility of educational opportunities. However, few policy efforts have ever been experienced in employability enhancement. Some findings on graduate employability were reported [Andrews and Higson, (December 2008), p. 420)], as experienced in four European countries, UK, Austria, Slovenia and Romania, which should be useful for the US policy consideration as well. They found that 'core components' of business graduate employability, as defined by "the value of hard business-related knowledge and skills; the importance of soft business-related skills and competencies; and the need for prior work-experience," were noticeably perceived to be similar by both groups of graduates and employers.

The problem of today's legislature is that it has become extremely intrusive in the economy. In the coming sections, an analysis of current policies, as well as suggestions to improve ineffective laws will be displayed.

Some economists and politicians, such as Reich (2014), Hamzaee (2016) and Sanders (2014), recommend better regulations followed by better implementation accordingly. Three other authors (Dyck et al., February 2013) estimated the percentage of firms engaged in fraud as well as the consequential cost of fraud. They reported that there was an estimated chance of $14.5 \%$ in any given year that a company would engage in a fraud. The loss as a result of fraud is not 
too small to ignore under the rosy promises of more extensive enterprise freedom that would necessitate no or minimum government regulations. They also estimated that corporate fraud resulted in investors losing 22 percent of the fraud-committing company's value and an average rate of 3 percent of enterprise value across all firms.

Table 1: Corporate Fraud and Weakening Trends of Legal Consequences

\begin{tabular}{lccccccc}
\hline & FY 2015 & FY 2014 & FY 2013 & FY 2012 & FY & FY & FY \\
& & & & & $\mathbf{2 0 1 1}$ & $\mathbf{2 0 1 0}$ & $\mathbf{2 0 0 9}$ \\
\hline Investigations Initiated & 75 & 88 & 60 & 80 & 110 & 116 & 123 \\
$\begin{array}{l}\text { Prosecution } \\
\text { Recommendations }\end{array}$ & 35 & 54 & 66 & 67 & 79 & 91 & 86 \\
Indictments/Information & 29 & 65 & 60 & 59 & 81 & 80 & 90 \\
Sentenced & 43 & 79 & 40 & 78 & 82 & 61 & 72 \\
Incarceration Rate* & $81.4 \%$ & $72.2 \%$ & $90.0 \%$ & $83.3 \%$ & $81.7 \%$ & $77.0 \%$ & $77.8 \%$ \\
Average Months to Serve & 35 & 40 & 67 & 47 & 51 & 48 & 43 \\
\hline
\end{tabular}

*Incarceration Rate includes confinement to federal prison, halfway house, home detention, or some combination thereof. Data Source: Criminal Investigation Management Information System. Organized and tabulated by Hamzaee (2016). Also:

https://www.irs.gov/uac/Corporate-Fraud-Criminal-Investigation-\%28CI\%29

The above tabulated information, followed by the following Figures, transpire the weakening trend of punitive consequences of various stages of fraud, which would be in line with serious concerns about a lack of effective government rules and regulations governing greed and corporate crime.

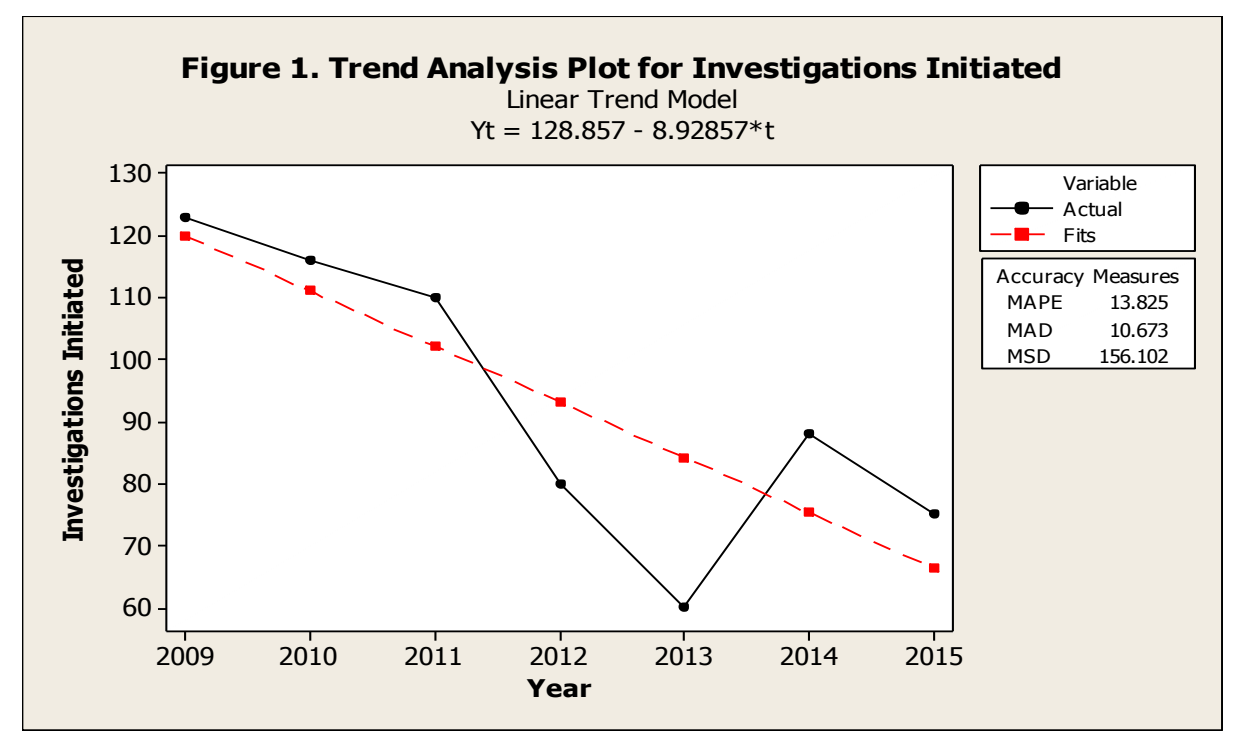



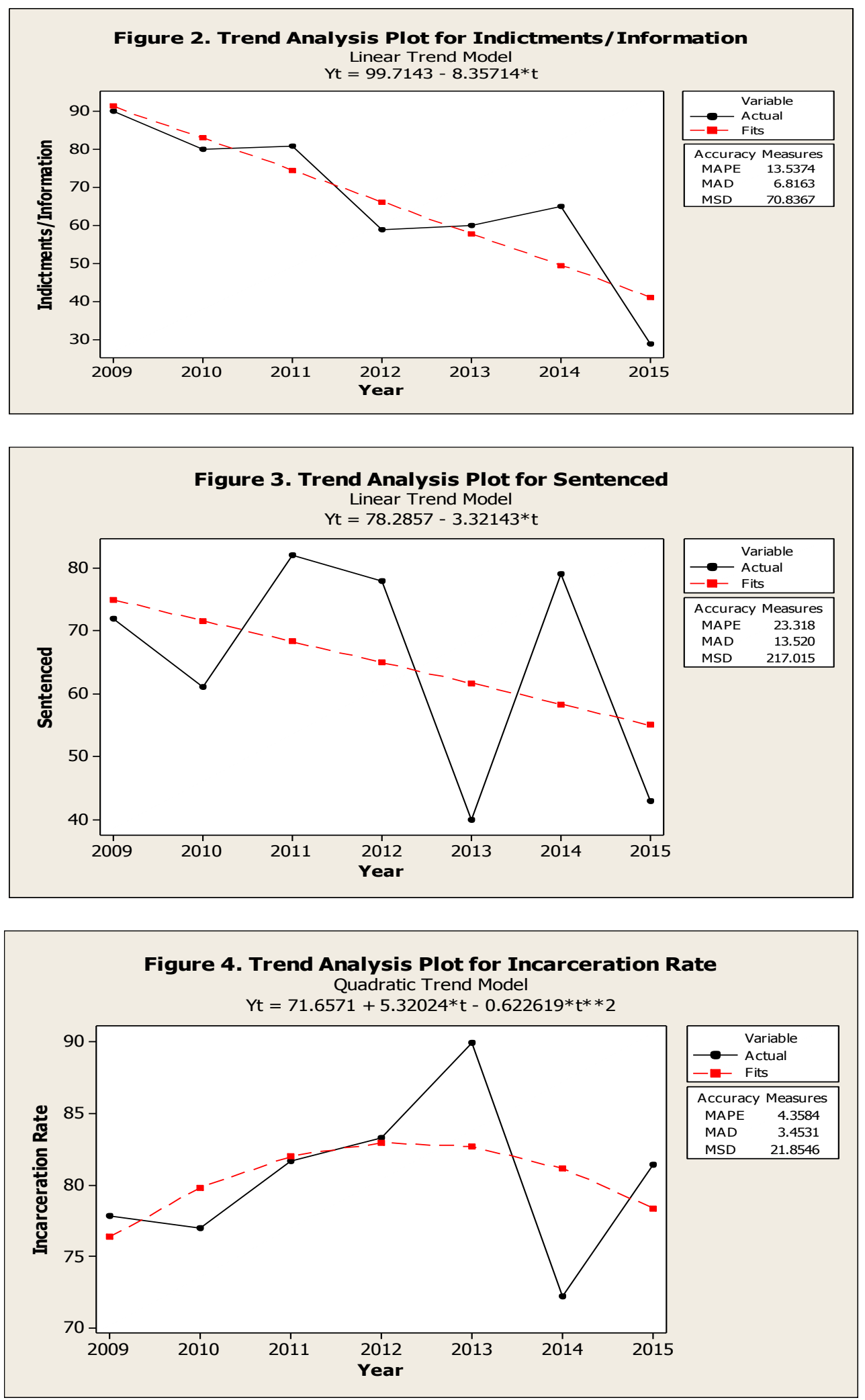

When a linear trend model was applied, among all the variables tested, the only upward trend experienced was about the incarceration rate, which was ruled out by a more valid quadratic trend model, through its lower estimated error measures. 


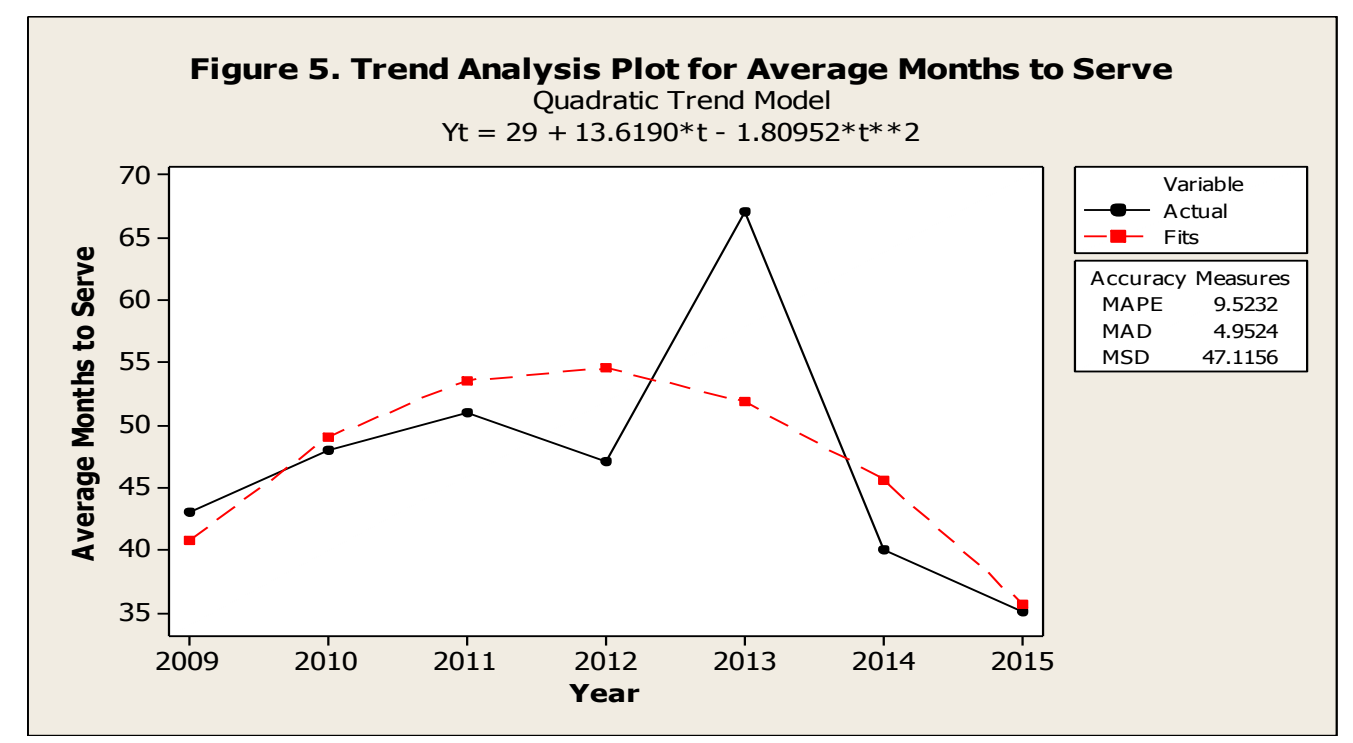

In regards to the current standing of capitalism and democracy, the true problem seems to be that a balance has not been appropriately explored. These two can often be at odds, since democracy becomes dedicated to a form of relative equality of opportunities and voting power, irrespective of financial strength of individuals in well-established countries, but capitalism remains predicated upon competition. Thus, there are intrinsic issues, and a balance between the two has not yet been achieved and remains to be a policy challenge in America and many other countries.

Of course, there are benefits to both democracy and capitalism; economic freedom and political freedom are both important to citizens in their own right. However, sacrifices must be made in order for the two to coexist. For example, capitalism must be regulated in instances of negative externalities, even from the strongest market-oriented economists' perspectives. Also, the leaders of a democracy may have to accept that a complete equality will never be achieved. More of the efforts have been centered on enhancement of equality of opportunities than other non-productive forms of equality. Yet, policies can bolster both democracy and capitalism despite some sacrifices between the two.

In terms of policy efficiency, economists and politicians are divided on the aspect of capitalism and regulations and/or the extent and scope of regulations. More conservative economists and politicians argue that the U.S. government has become heavy-handed, in adopting too much regulation, through which it has put a strain on economic growth, economic efficiency, and the ability of businesses to prosper. As stated previously, the government has intervened in many areas, which has prevented the market from playing its automatically built-in stabilizing role and addressing the corresponding issues.

For example, farmer's subsidies cost taxpayers a large amount, and they are often paid to farmers who do not produce crops (Economist, Feb 14, 2015). The government has become involved in order to help citizens and foster a sense of equality, but there have been multiple unplanned negative effects. Those subsidies would ultimately cost the tax payers higher prices than market would necessitate. In absence of such intervention, more efficient farmers could stay and those who do not necessarily belong in farming would switch to other more productive activities, which are more beneficial to themselves and the public.

Another example is that of low-income housing. These establishments are often of poor quality in achieving any noticeable goals. There would appear, with no exception, a shortage of this 
resource, leading more often than otherwise to under-the-table payments. Affordable housing is important, but there is likely a better way to achieve this goal. A better alternative, which is also used currently, could involve addressing the vast income inequality in America, and promoting easier credit accessibility to make middle-income housing more affordable. This exemplifies that policies can impact the harmony of markets and that the government can become too involved in the economy, which has happened on various occasions and often produced few benefits.

Almost all regulations often impede competition, which is a serious problem since capitalism is predicated upon competition (Coyne 2007). Competition keeps prices low and allows markets to function in an efficient manner, in absence of any externalities and market failure. Yet, in the case of rent control, regulated prices would be below equilibrium levels, causing shortages, and in case of price floors in farming sector, there would appear surpluses and higher prices unnecessarily. Furthermore, government intervention often makes it more expensive for businesses to operate; especially with the length and complexity of current legislation. These extensive regulations make business operation more costly requiring extra work.

These regulations can be ineffective, but they are often still needed. For example, low-income housing is a good resource for many citizens, and farmers subsidies have allowed citizens to continue making a living when business is poor. This is important in the aims of equality. However, there might be better ways to approach this. Fostering a strong economy in general and raising the minimum wage could be effective. A strong economy would foster job creation, and a fair wage would allow citizens to provide for themselves. In this scenario, farmers would be able to make a living (by finding another means of employment) if they could not profit from agriculture, and low-income housing would have less demand since individuals were making more. It appears that some of our current policies address the effects of economic issues, not the direct causes. Some true problems in America are income inequality, lack of a fair wage, etc. Policy attempts to address these issues to a certain extent, but the government addresses specialized issues instead of broad-sweeping problems. As stated above, improving the economy and creating a fair wage could eliminate or drastically reduce the need for farmer's subsidies, low-income housing, and many more inefficient policies.

With that being said, one must explain these major problems, why policies have not addressed them, and what can be done to address these issues. A major issue discussed previously is that of an increasingly too disproportionate income inequality. Policies often foster income inequality, such as that of trickle-down economics. It appears that this policy has allowed the affluent to become better off, and it has made the poor become worse off. Further, there are various tax loopholes in the US, which have allowed the rich to make more of a profit. Lowe and Williams (2012) explain that out of the 280 largest corporations in the United States, 78 did not pay taxes, or even had a negative tax rate, for at least one year since 2008. They also detail a study conducted in 2010 by Global Financial Integrity, which found that a total sum of about $\$ 9.4$ trillion dollars was hidden away in offshore accounts across all continents. These loopholes have allowed the rich to become even wealthier since the government cannot tax them effectively. Due to this, the income gap has increased, and the rich maintain control over more and more of money in circulation. These are pinnacle examples of how policies have allowed income inequality to grow and fester.

Now that some causes of income inequality have been reviewed, one must explain why this is truly an issue in America. First and foremost, one must turn to the importance of the middle class. Middle-income citizens are the spenders in an economy. They spend on a regular basis in buying durable goods, such as housing, refrigerators, and cars. In contrast, the rich, who - in 
addition to those regular spending patterns - often invest and/or save their surplus funds for prospective spending and future generations. Even worse, the poor do not even have enough to spend. The poor are proven to be more inactive in voting and they do not participate in advocating for needed changes of any socioeconomic policies. Thus, a strong middle class is crucial to a thriving economy. Yet, a widely disproportionate income inequality does not allow this to happen. In fact, some of the largest economic crises in America, and the world, have happened in times of large inequality. Lansley (2012) explains that income inequality in America has been a U-Curve; meaning that inequality was quite high in the 1930s during the time of the Great Depression. Then, it was greatly reduced afterwards, and it was low in the 1970s (the economy was fairly stable in this time period). Finally, inequality had almost reached the levels of before the Great Depression in 2007, before the Great Recession took place. This demonstrates that income inequality, if not a hindrance to the strength of an economy, has surely appeared with a weakening economy. In fact, the two largest economic downturns in the history of America have occurred in times of drastic inequality. The following charts demonstrate that income inequality is still an issue in America, and that it has actually been worsening as of late, which is quite possibly, due to policy failures and/or inefficacy, at a minimum.

Figure 6 demonstrates that wealthy citizens continue to prosper while poor citizens are actually doing worse. If capitalism should be saved from its possible collapse through an increasing growth of many nations' public dissatisfaction with their governments and establishments, appropriate policies should seek to address and alleviate this problem. If better policies are created, then other needs for regulation, such as those listed above, will probably decrease. This will address the cause of many economic problems, not merely the effects. In terms of how to fix income inequality, there are multiple options, one of which is reducing tax loopholes and raising taxes on the rich, which will allow more effective government spending towards social welfare.

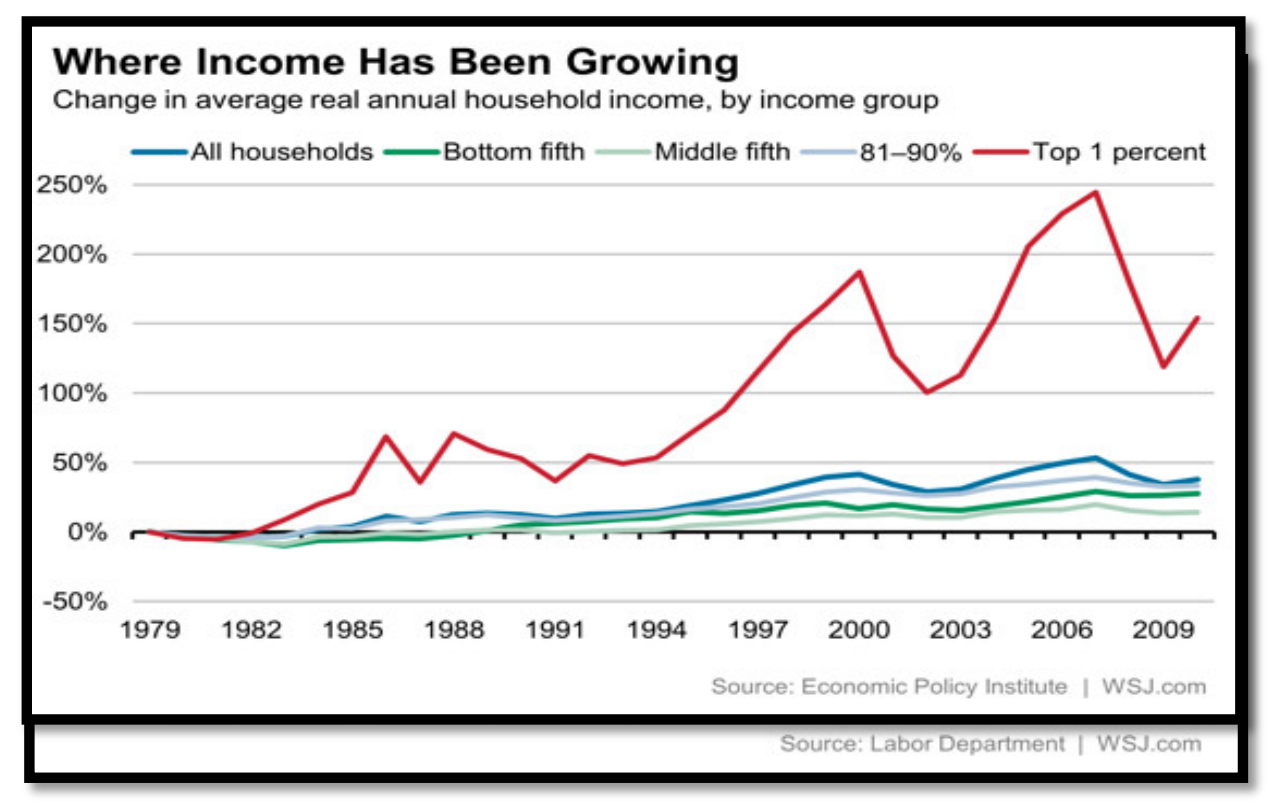

Figure 6: Income Growth \& Widening Trend of Inequality

Another method to address the income gap is raising the minimum wage. Currently, this wage is not fair. Many can work full time while making $\$ 7.25$, but they will still be below poverty lines. In fact, individuals can often make more on welfare than working at minimum wage. Hamzaee (2006) argues that if minimum wage were just to keep on pace with inflation since 
1976, when the Federal minimum wage level was $\$ 2.30$ per hour, then it should have increased to $\$ 8.79$ in 2006 , given the average annual inflation rate of $4.42 \%$ and in that line of reasoning, it should have been close to $\$ 13.55$ per hour in 2016 . Yet, the current Federal minimum wage, as of 2016 , is $\$ 7.25$, which means that those who are making minimum wage actually have less purchasing power than those on minimum wage 40-41 years ago. Income inequality is a serious problem in America, and government must address and alleviate this problem through appropriate policy, or our economy could continue to struggle and further economic crises could ensue.

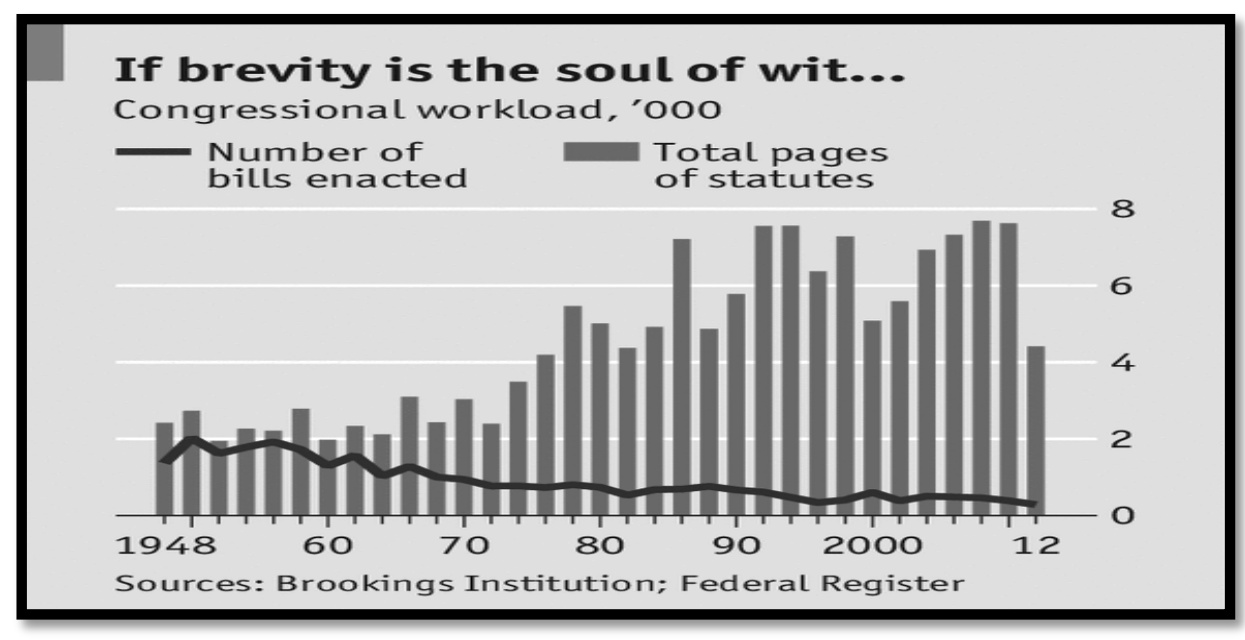

Figure 7: Growing Congressional Inefficiency

To make things even worse, U.S. Congressional inefficiency is on the rise, which has hindered policymaking in America. One simple way to measure this is by comparing the number of laws enacted by recent Congressional sessions. The 113th Congress, which was in session from 2013-2015, enacted 296 laws (Govtrack, December 2016). Compare that to the 106th Congress, which was in session from 1999-2001 and enacted 604 laws. The Congressional session in place from 1981-1989 enacted an average of 661. This can partially be explained because bills have become more complex, as shown below.

In 1948, the average bill was two and a half pages long. Today, bills are around 20 pages on average (The Economist, Nov 23, 2013). This arises because it is difficult to pass legislation with individual representatives under the influence and financial backing of lobbyists, who often add provisions and earmarks to a must-pass or a significant bill. This can explain why the No Child Left Behind Bill of 2001 was over 1,000 pages, and the Affordable Care Act passed in 2010 was over 2,400 pages. These large bills create an environment in Congress where representatives are not entirely sure what they are voting due to the sheer size of legislation. Further, these massive bills make it difficult for businesses to comply with them, which would naturally lead to further policy inefficiency.

Overall, current policy making has not demonstrated that capitalism and democracy fuse well together. Yet, this does not have to be the case. Further, a shrinking middle class and high income inequality have thrived under current policy, but this is unacceptable. Policymakers must address these issues, yet the current state of Congress, which embodies a lack of compromise and action, makes it difficult to create effective policy. As such, policies are not adapting as needed, and, thus, the economy, and America in general, are suffering. More efficient policies must be implemented in order to address the serious issues of the American economy, and this is of utmost importance if the American economy is to become and remain prosperous. 


\section{A THEORETICAL MODEL AND ANALYSIS OF OPTIMAL GOVERNMENT PRODUCTION POSSIBILITIES}

The authors propose the following theoretical framework for an optimal governmental production possibilities function, in which all major public goods and services that are supposed to be produced and provided by government are included and represented by $\mathrm{Q}_{1}$ and $\mathrm{Q}_{2}$.

Let $\mathrm{Q}_{1}$ measure the total indexed quantity of the first group (inclusive of, e.g., Social Security, Medicare-Medicaid, low-cost or free housing, education) and $\mathrm{Q}_{2}$ measure the total indexed quantity of the second group, inclusive of, e.g., national defense, domestic security, law and order. Government's responsibility is supposed to be met in an optimal fashion to provide a collective prosperity and comparable costs to all groups of a nation. A prudent government, like any other financially responsible individuals or business organizations, must maintain a separate reserves account for all other projects and unforeseeable expenses above and beyond what its primary responsibilities, as listed above, would require. Various solutions for a national group optimization would be analyzed.

Beginning with the two general output groups of public goods to be produced, there are $n$ different resources to be used in production of each good. Therefore, the $n$ resource constraints are defined as:

$$
\begin{aligned}
& a_{11} Q_{11}+a_{12} Q_{12} \leq R_{1} \\
& a_{21} Q_{21}+a_{22} Q_{22} \leq R_{2} \\
& \ldots \ldots \ldots \ldots \ldots \ldots \\
& a_{n 1} Q_{n 1}+a_{n 2} Q_{n 2} \leq R_{n}
\end{aligned}
$$

\section{Defining:}

$a_{i j}=$ the amount of the $\mathrm{i}$-th resource necessary to produce one indexed unit of group $\mathrm{j}$ of public good output (as described above), for $i=1,2, \ldots, n ; j=1,2$

$\mathrm{Qij}_{=}$the total indexed quantity of the $\mathrm{j}$-th group of public good produced by the $\mathrm{i}$-th resource

$\mathrm{R}_{\mathrm{i}}=$ The total quantity of the $\mathrm{i}$-th utilized resource

$\mathrm{i}=1,2, \ldots, \mathrm{n}$ resources and

$\mathrm{j}=\quad 1,2$ output groups of public goods produced by government

In Figure 8, we are applying the linear programming technique, and as an illustrating example, assume that we have only five $(n=5)$ of the aforementioned hypothetical resources, and the 5 resource constraints are graphed accordingly to make up a production possibility frontier for government. Obviously, to arrive at a relevant production possibilities frontier (the darker portions of the five constraints), all of the nth resource constraints listed above in (1), must be simultaneously implemented. An integration of all the resource constraints for government would be summarized in constraint (2), as follows next.

$\left(Q_{1}\right)$

Indexed

quantity of

group-one public

goods output 


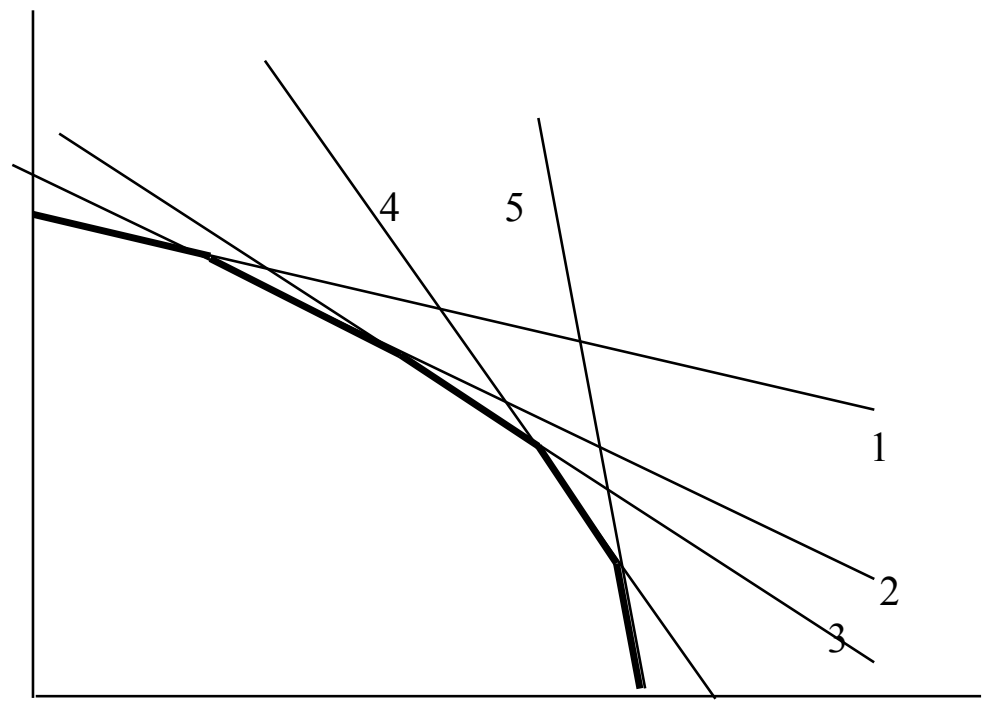

(Q2) Indexed quantity of group-two public goods output

Figure 8: Government Production Possibilities Frontier for Production of Two Groups of Public Goods

Obviously, it is expected that more investment in employability of the labor force would lead to an outward shift in the production possibilities frontier which would result in expansion of productivity and economic growth.

$$
\sum_{i=1}^{n}\left(a_{i 1} Q_{i 1}+a_{i 2} Q_{i 2}\right) \leq \sum_{i=1}^{n} R_{i}
$$

Such resources, as an example, could include - but not limited to - the following list:

$\mathrm{R}_{1}=$ Labor

$\mathrm{R}_{2}=$ Financial capital

$\mathrm{R}_{3}=$ Number of security personnel

$\mathrm{R}_{4}=$ Number of security facilities

$\mathrm{R}_{5}=$ Physical capital

$\mathrm{R}_{6}=$ Rental resources

$\mathrm{R}_{7}=$ Healthcare resources, etc.

\section{The Government Budget Line}

Then through a recommended and ideally efficient operation, a hypothetical competitive model with the following condition should fit:

$$
\mathrm{P}_{1}=\mathrm{ATC}_{1}
$$

Also, by definition:

$$
A T C_{1}=\frac{\sum_{i=1}^{k} r_{i} R_{i}}{Q_{1}}
$$

Definition (4) is the average resource cost, considering $\mathrm{k}$ different resources to be used for provision of output $\left(Q_{1}\right)$.

$\mathrm{P}_{1}=$ Indexed average price of a composite unit of output group 1

$\mathrm{Q}_{1}=$ Quantity of a composite indexed output of group-1 public goods \& services 
$\mathrm{ATC}_{1}=$ the average total cost of all resources needed for each composite unit of output group 1 to be produced in a certain period of time

$r_{i}=$ the rental price (cost) of the ith resource in production of output for $\mathrm{i}=1,2, \ldots, \mathrm{k}$

Comparing (3) and (4), the following definition, under competition, will result:

$$
P_{1}=\frac{\sum_{i=1}^{k} r_{i} R_{i}}{Q_{1}}
$$

Also, $\mathrm{P}_{2}$, the price of a composite indexed quantity of output group $2\left(\mathrm{Q}_{2}\right)$, can similarly be defined as:

$$
P_{2}=A T C_{2}=\frac{\sum_{j=1}^{m} r_{j} R_{j}}{Q_{2}}
$$

$\mathrm{ATC}_{2}=$ average total cost of all composite indexed quantity of output group 2 supplied in a certain period of time

$r_{j}=$ the rental price (cost) of the ith resource in production of output group 2 for

$\mathrm{n}=\mathrm{k}+\mathrm{m}$

Then the following relationship (7) will represent the budget constraint for government, through taxes, still within the assumption of government's efficiency in which case its incomes under competitive conditions would be the same as its total costs:

$$
\begin{aligned}
& P_{1} Q_{1}+P_{2} Q_{2} \leq B \\
& B=B_{1}+B_{2}
\end{aligned}
$$

$B_{1}$ and $B_{2}$ represent government's designated budget for providing an optimal composite indexed quantity of output group $1\left(\mathrm{Q}_{1}\right)$, and output group $2\left(\mathrm{Q}_{2}\right)$ of the public goods and services, respectively. So, B is the totality of government's budget, excluding its extra reserve account for emergency purposes, as described before.

Now, plugging (5) and (6) in (7), the following budget constraint will be resulted:

$$
\begin{gathered}
\frac{\sum_{i=1}^{k} r_{i} R_{i}}{Q_{1}} \cdot Q_{1}+\frac{\sum_{j=1}^{m} r_{j} R_{j}}{Q_{2}} \cdot Q_{2} \leq B \\
Q_{1}=\left[\frac{B}{\sum_{i=1}^{k} r_{i} R_{i}} \frac{\sum_{j=1}}{Q_{1}}\right] \\
\left(Q_{1}-\text { Intercept }\right) \quad \text { Slope of government's budget constraint }
\end{gathered}
$$




$$
Q_{1}=\left(\frac{\text { Total government budget }}{\text { government's average cost of operation }}\right)-\left(\frac{\text { ATC of group } 2 \text { public goods }}{\text { ATC of group } 1}\right) \cdot Q_{2}
$$

The last relationship (9) could be interpreted as an easy-to-follow optimal rule of how the indexed quantities of the two public-good groups should be related.

Now all government and the public are put together into interaction, and we find various possible optimization solutions to the model. In Figure 9, the optimum solution for government's supply and the public's consumption of the two groups of the public goods is the same, $\mathrm{Q}^{*}{ }_{1}$ and $\mathrm{Q}^{*}{ }_{2}$ should be produced and consumed. The utility function for an individual consumer of the two groups of the public goods is represented by (10), as follows:

$$
\mathrm{U}=\mathrm{U}\left(\mathrm{Q}_{1}, \mathrm{Q}_{2}\right)
$$

The collective utility (social welfare) function for all consumers, or the nation, would be defined accordingly as:

$$
\mathrm{W}=\mathrm{W}\left(\mathrm{Q}_{1}, \mathrm{Q}_{2}\right)=\mathrm{U}_{1}\left(\mathrm{Q}_{1}, \mathrm{Q}_{2}\right)+\mathrm{U}_{2}\left(\mathrm{Q}_{1}, \mathrm{Q}_{2}\right)+\ldots . .+\mathrm{U}_{\mathrm{p}}\left(\mathrm{Q}_{1}, \mathrm{Q}_{2}\right)
$$

Which would include all 1, 2, 3, ...,p individuals in the population.

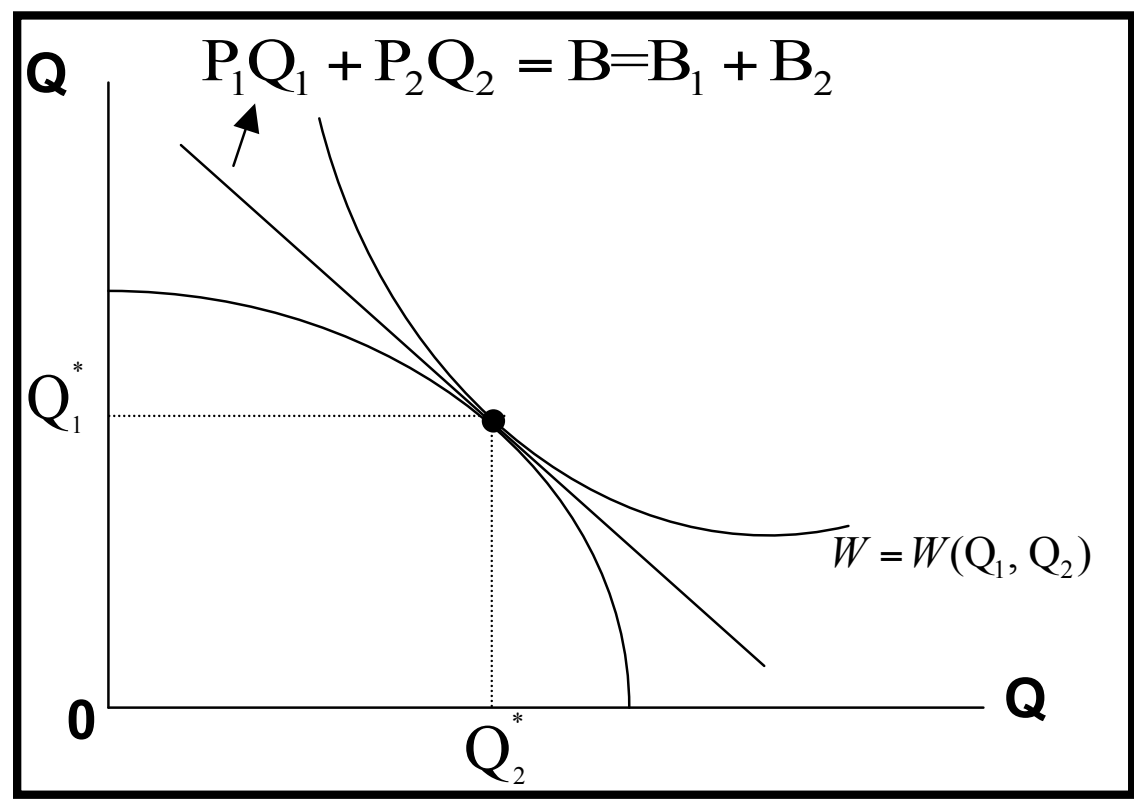

Figure 9: The Optimal Solution for Government and the Public

In Figure 10, consumers of both services would have a different optimal solution than would government. The consumers' preferences are more heavily towards the first groups of public goods and services $\left(\mathrm{Q}_{1}{ }^{\text {cons }}>\mathrm{Q}_{1}{ }^{*}\right)$, and relatively less for the second group. 


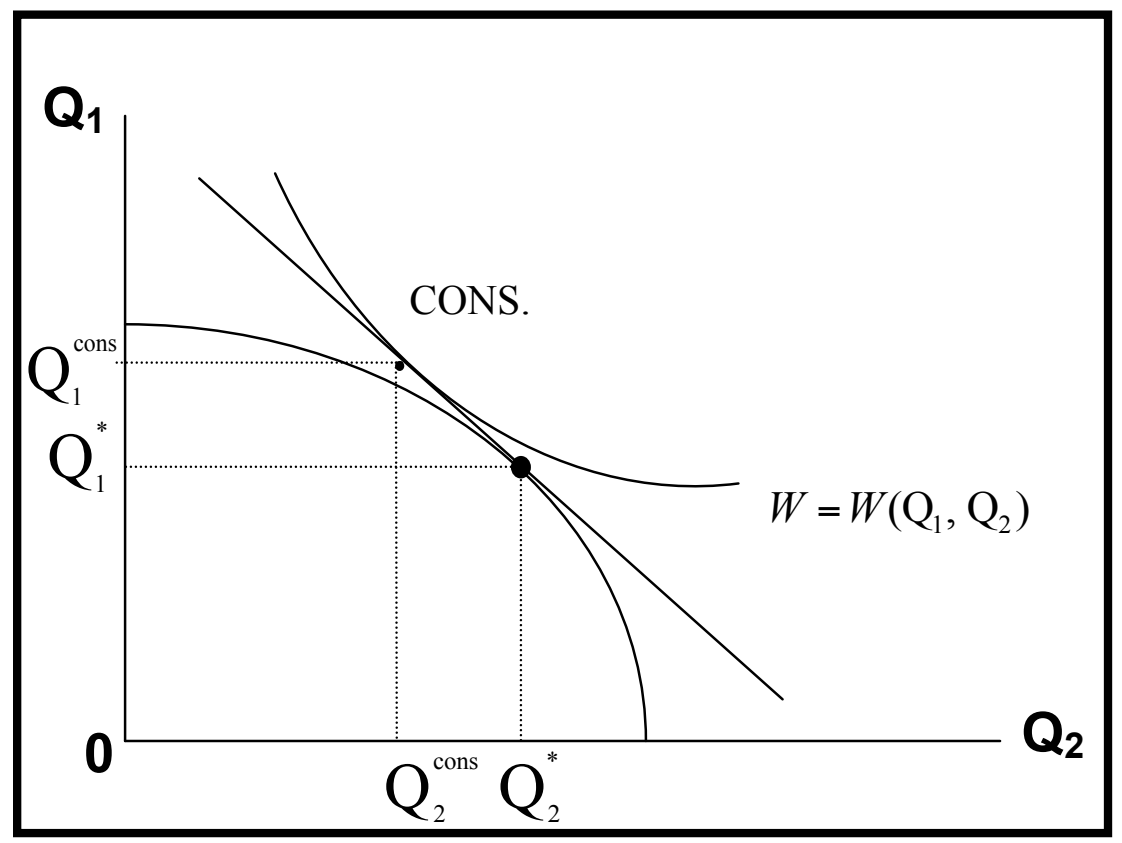

Figure 10: Different Preferences for Consumers and Government

In the following case (Figure 11), the providers will have again a different optimal solution than the consumers would. Consumers reveal more preference of group 2 than group 1 public goods and services.

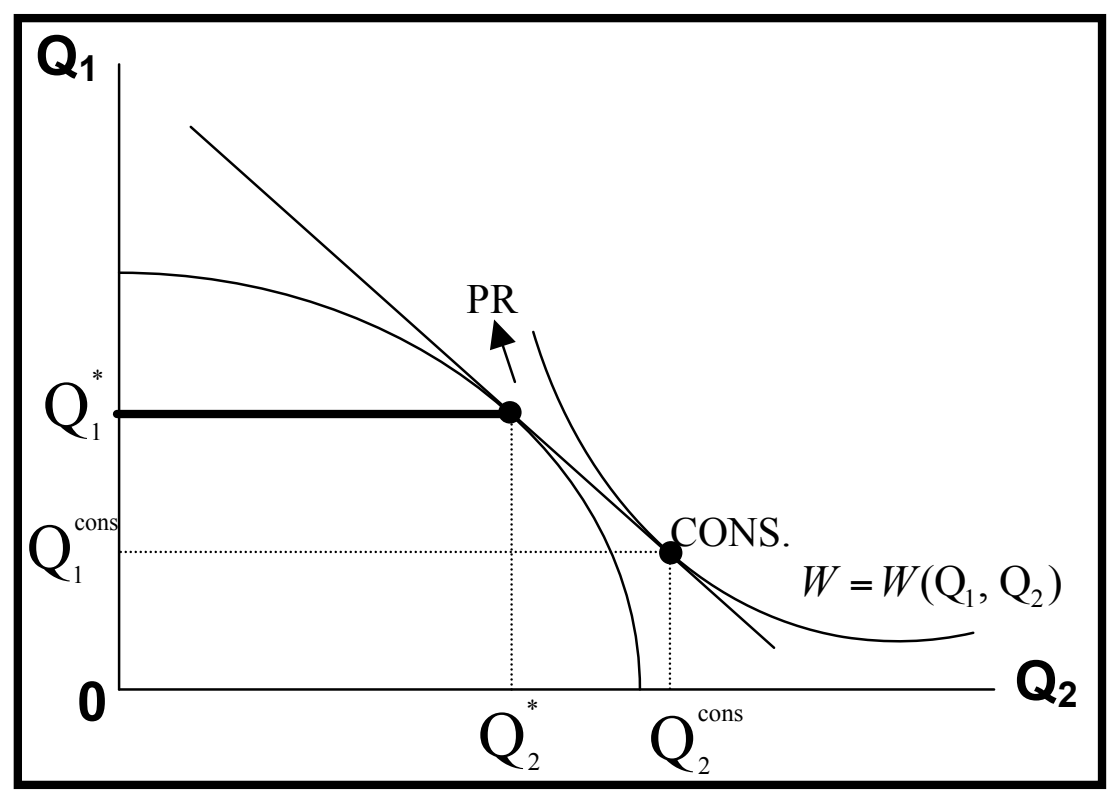

Figure 11: Consumers' Biases Are Towards Second Group

Hamzaee (2016) studied 57 countries with available comparable data to discover the main factors, alongside their corresponding weights of explaining "quality of life" in ranking the best countries for living, his statistically significant regression estimation results as summarized below: 
Table 2: Regression Variables Definition

\begin{tabular}{|l|}
\hline QLI = Quality of Life Indicator \\
\hline SI = Safety Index \\
\hline HCI = Health Care Index \\
\hline PPIR = Property-Price-to-Income Ratio \\
\hline TCTI = Traffic-Commute-Time Index \\
\hline GI = Gini Index \\
\hline HDI = Human Development Index \\
\hline
\end{tabular}

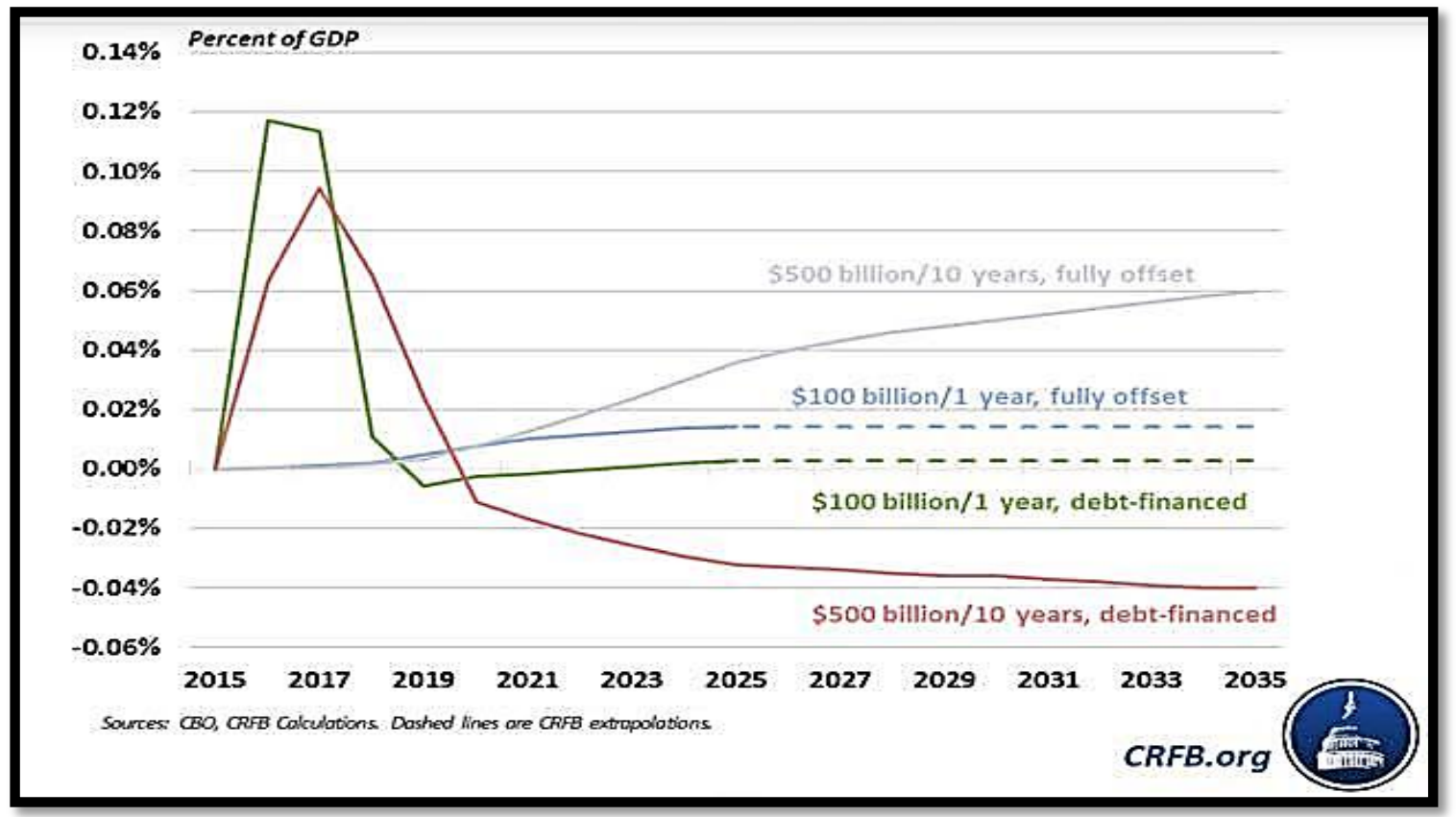

Figure 12: Change in GDP from Various Investment Options

\section{CONCLUSION}

It is urgent for all nations to review and explore most cautiously all the challenging options that are still open to them to reverse the ongoing socio-economic imbalances before the current devastating damages grow out of control. Societies need to be sustainable, and as such, it is urgent to create built-in public policy stabilizers. The growingly destructive roles of lobbyists, whose ultimate objective is to corrupt a healthy economic system, governed by the donors of mega bucks in exchange for distorted economic policy would eventually lead to a huge systemic eruption and devastating riots and revolutions. All public policy needs to be focused on and concerned about is how to enhance the collective prosperity of a nation through a dynamic employability planning and exploration of all the innovative as well as systemic methods of enhancing the size and legitimate influence of the middle class. The security and health of the working class is like an assured solidification of the foundation of a high rise, for which an ongoing appropriate legislation is mandatory.

The healthy growth and support of business are together another necessary piece of an advanced policy. In absence of friendly business policies within some ethically acceptable standards, societies cannot advance to their potential limits. Capitalism and democracy are still proven to be more conducive to mental and material prosperity than any other known systems. The best countries to live in are globally and practically assessed to be the ones that have provided more quality of life. Empirical studies confirm that quality of life, itself is explained and summarized by many nations in meaningful indices, such as safety, health care, affordable properties (housing), shorter commuting time to work, human development, and 
relatively more of income equality, which is defined as less excessive and unjustifiable income inequalities.

\section{References}

Almond, G. (1991) Capitalism and Democracy. PS: Political Science and Politics, Vol. 24, No. 3, pp. 467-474. DOI:1. Retrieved from http://www.jstor.org/stable/420091 doi:1 (Accessed 19 July 2016).

Andrews, Jane and Higson, Helen (December 2008). Graduate Employability, 'Soft Skills' Versus 'Hard' Business Knowledge: A European Study. Higher Education in Europe. Vol. 33, No. 4, pp .411-422.

Blumen, J. (1996) Capitalism and Democracy. http://www.spectacle.org/496/demo.html (Accessed 19 July 2016).

Bondioli, S. (2014) U.S. Policies Favor the Wealthy, Interest Groups, Study Shows. http://www.huffingtonpost.com/2014/04/15/government-wealthy-study_n_5154879.html (Accessed 11 June 2016).

Coyne, C. (2007) Capitalism and Democracy: Friends or Foes?. Retrieved from

http://www.economist.com/blogs/freeexchange/2007/08/guest_blogger_chris_coyne (Accessed 19 July 2016).

Criminal Investigation Management Information System. (2016) Reported by Hamzaee (2016). Also:

https://www.irs.gov/uac/Corporate-Fraud-Criminal-Investigation-\%28CI\%29 (Accessed 10 September 2016).

De Vosa, Ans; De Hauwb, Sara, and Van der Heijdenc, Beatrice I.J.M (October 2011). “Competency Development and Career Success: The Mediating Role of Employability. Journal of Vocational Behavior. Volume 79, Issue 2, pp. 438-447.

Duke, B. (2015) New Data Illustrate the Failure of the Trickle-Down Experiment. https://www.americanprogress.org/issues/economy/news/2015/06/29/116130/new-data-illustrate-thefailure-of-the-trickle-down-experiment/ (Accessed 9 July 2016).

Dyck, Alexander; Morse, Adair, and Zingales, Luigi. (February 22, 2013) "How Pervasive Is Corporate Fraud?" Rotman School of Management Working Paper No. 2222608.

Edsall, T. (2014) Capitalism vs. Democracy. http://www.nytimes.com/2014/01/29/opinion/capitalism-vsdemocracy.html (Accessed 19 July 2016).

Esposito, E. (2014) Capitalism and Democracy: Oil and Water. Global Studies Journal, Vol. 6, No.3, pp. 33-46.

Govtrack. Statistics and Historical Comparison. Retrieved from

https://www.govtrack.us/congress/bills/statistics (Accessed 21 December 2016).

Hamzaee, Reza G. (October 2016) “Free-Markets' Sustainability: Socio-economic Policy Analysis.” The Journal of Global Academic Institute Business \& Economics. (JGAIBE), Vol. 2, No. 3, pp. 15-30. (ISSN: 2375-9534).

Hamzaee, R. (December 17, 2006) “Minimum Wage Hike Works: Conservatives Can Embrace Missouri's New Minimum Wage Law," St. Joseph News-Press, p. A6.

Hutchinson, M. (2013) The United States as a New Haven of Economic Inefficiency. Retrieved from http://www.theglobalist.com/the-united-states-as-a-haven-of-economic-inefficiency/

Krutz, G. S. (2015) Gridlock and Divided Government in the U.S.

http://www.oxfordbibliographies.com/view/document/obo-9780199756223/obo-9780199756223-0112.xml (Accessed 7 August 2016).

Lansley, S. (2012) Inequality, the Crash and the Ongoing Crisis. Political Quarterly, 83(4), pp. 754-761.

Lowe, H. A., \& Williams, N. (2012) Closing Tax Loopholes. OECD Observer, (290/291), p. 55.

Patterson, K. D., \& Magleby, D. B. (1992) The polls -- Trends: Public Support for Congress. Public Opinion Quarterly, Vol. 56, No. 4, p. 539.

Perry, P. M. (2015) Assessing Obamacare. LP/Gas, Vol. 75, No. 3, p. 72.

Reich, Robert. (May 12, 2014) "How to Shrink Inequality" http://robertreich.org/post/85532751265 (Accessed 11 July 2016).

Rozell, M. J. (2000) The Press and Congress: Perspectives on Political Science, Vol. 29, No. 2, p. 71. 
Sanders, Bernie. (2014) "Senator Bernie Sanders Unveils 12 Point Economic Plan."

.http://crooksandliars.com/2014/12/bernie-sanders-unveils-12-point-economic (Accessed 9 June 2016 ).

Sinclair, B. (2009) Question: What's Wrong with Congress? Answer: It's a Democratic Legislature. Boston University Law Review, pp. 387-398.

Solomon, J. (2014) Top 10 Companies Lobbying Washington.

http://money.cnn.com/2014/10/01/investing/companies-lobbying-10-biggest-spenders/ (Accessed 9 June 2016).

The Economist (Feb 14, 2015) Milking Taxpayers. Retrieved from http://www.economist.com/news/unitedstates/21643191-crop-prices-fall-farmers-grow-subsidies-instead-milking-taxpayers (Accessed 5 May 2016 ).

The Economist (Nov 23, 2013) Outrageous Bills. Retrieved From http://www.economist.com/news/unitedstates/21590368-why-congress-writes-such-long-laws-outrageous-bills (Accessed 5 May 2016).

The Economist (February 16, 2012) Over-regulated America. http://www.economist.com/node/21547789 (Accessed 5 May 2016).

Topaz, J. (2014) 'Worst Congress Ever,' by the numbers. http://www.politico.com/story/2014/12/congressnumbers-113658 (Accessed 15 November 2016).

Weller, C. E. (2012) 10 Reasons Why Public Policies Rescued the U.S. Economy. https://www.americanprogress.org/issues/economy/news/2012/05/29/11593/10-reasons-why-publicpolicies-rescued-the-u-s-economy/ (Accessed 12 August 2016).

Zumbrun, J. (2015) What We Know about Inequality (in 14 Charts).

http://blogs.wsj.com/economics/2015/01/01/what-we-know-about-inequality-in-14-charts/?mg=id-wsj (Accessed 12 August 2016). 